\title{
REFORMASI KELEMBAGAAN DAN KEMANDIRIAN PEREKONOMIAN PEDESAAN
}

\author{
Oleh M. Ilyas
}

Dalam tiga empat dekade terakhir terdapat dua peristiwa pergolakan politik berskala besar, yaitu berkaitan dengan pergantian pemerintahan (dari Orde Lama ke Orde Baru dan dari Orde Baru ke Orde Reformasi ), yang di dalamnya terkandung adanya krisis pangan ( terutama ketersediaannya beras) yang relatif berat.

Dalam keadaan masyarakat di sekitar perkotaan ( Jawa) dihadapkan pada kesulitan memperoleh bahan pangan ( beras ), maka bayangan jebakan krisis subsistensi ( Scott, 1989 ) bersamaan dengan krisis ekonomi (1998) benar-benar menjadi kenyataan.

Sejak memasuki dekade 1990-an memanh terasa ada semacam "kelalaian politik " untuk mempertahankan spirit berswasembada beras secara nasional, dan kelalaian itu saat ini harus dibayar mahal oleh masyarakat pedesaan dalam bentuk keterbelakangan nya dibidang ekonomi.

Untuk mengatasi keterbelakangan ekonomi pedesaan yang sudah

menahun ini, diperlukan langkah reformatif atau menurut istilah Kuhn (1967) disebut revolusi paradigma ( kelembagaan pedesaan ). Langkah yang sifatnya "tambal sulam " atau setengah hati justru hanya akan membuang-buang waktu dan memboroskan sumber daya yang ada. Reformasi kelembagaan dalam tulisan ini dapat diartikan sebagai " to make ( performance of rural economics institutions) better by putting or stop abuses or malpractices or by introducing better institutions ". Lebih lengkap lagi jika makna reformasi kelembagaan ekonomi ini terkait erat dengan reformasi di bidang kehidupan sosial dan politik pedesaan.
Dewasa ini gejala mungkin dalam waktu singkat "efek kehancuran ekonomi padi sawah di Indonesia, yang berawal dari kemerosotan efisiensinya, telah membayang di depan mata. Yang perlu dicemaskan dari kehancuran ekonomi padi sawah tadi bukanlah hanya pada besarnya devisa terkuras untuk impor beras, melainkan pada "efek domino" yang ditimbulkannya dalam kehidupan masyarakat di bidang ekonomi, sosial, budaya, dan politik. Bukan tidak domino" tadi akan menjelma menjadi kerentanan daya tahan perekononomian nasional karena rongrongan bahaya kerusuhan sosial yang meluas, semakin menajamnya konflik antara golongan "elit minoritas" masyarakat penguasa kapital dan golongan "massa-mayoritas" papa atau tidak berkapital, melemahnya solidaritas sosial, merosotnya keamanan dan bahaya disintegrasi bangsa. 
Salah satu faktor strategis yang menyebabkan daya saing perekonomian beras nasional kita relatif lemah adalah lemahnya sistem kelembagaan perekonomian pedesaan. Selama lebih dari tiga dekade sistem kelembagaan perekonomian pedesaan bukan saja tercabut dari akar budayanya, namun juga mengalami proses "pembusukan" secara sistematik. Sistem kelembagaan pedesaan yang hingga beberapa tahun terakhir secara politk masih terkooptasi oleh kebijakan pembangunan yang sangat sentralistik dan tersubordinasi oleh organisasi pemerintah pusat (Pranadji,1999 and Mac Andrews

dan Amal, 1995 ) sehingga dampak sosial ekonominya masih sangat terasa. Kerugian yang sangat mahal adalah kreativitas masayarakat pedesaan "lokal" tidak memperoleh ruang untuk berkembang sangat layak. Pada saat yang hampir bersamaan, dengan kinerja organisasi pemerintahan dan perekonomian padi secara nasioanl tidak efisien

dan sarat dengan Korupsi, Kolusi, dan Nepotisme (KKN), kepercayaan masyarakat terhadap penyelenggara negara sudah sangat merosot ke tingkat yang paling parah sejak kemerdekaan.

Reformasi kelembagaan pedesaan, sejalan dengan diberlakukannya otonomi (pemerintah) daerah, dapat dijadikan agenda penting untuk mengembalikan kekuatan ekonomi pedesaan. Dalam rangka meningkatkan daya saing kelembagaan dan sistem agribisnis padi sawah di pedesaan, seyogyanya makna otonomi tidak berhenti pada pemerintahan tingkat kabupaten atau tingkat II, namun bahkan harus sampai di tingkat komunitas pedesaan ( Pranadji, 2002 ). Oleh sebab itu makna reformasi dalam bingkai otonomi daerah harus mencakup pengertian pemberian kesempatan dan kepercayaan "trust" pada kelembagaan lokal untuk meningkatkan kapasitas, kecerdasan dan efisiensi di bidang pengelolaan sumber daya ekonomi, termasuk padi sawah. 


\section{SEJARAH : Politik dan Pangan}

Interaksi "ekonomi padi" dengan institusi politik telah banyak mewarnai perjalanan bangsa Indonesia untuk menunjukkan kemandiriannya sebagai negara yang berdaulat. Dengan sumber daya alam, kekayaan biodiversitas lokal dan potensi kekuatan lembaga perekonomian masyarakat pedesaannya tidak sepantasnya jika bangsa Indonesia menggantungkan kebutuhan berasnya pada pasar luiar negeri ( impor ) secara berkelanjutan. Terlebih lagi jika disadari bahwa sistem produksi beras nasional kita hingga dewasa ini masih menjadi bagian integral dari perekonomian masyarakat pedesaan.

Kegagalan dalam penyediaan beras, sebagai bahan strategis, akan bisa menimbulkan implikasi sosial dan politik yang bernilai sangat mahal. Akhir-akhir ini di kalangan perumus kebijakan pembangunan (ekonomi) berkembang pemikiran tentang liberalisasi pertanian, termasuk menyangkut masalah komoditas pangan strategis, khususnya padi. Ditinjau dari semangat untuk membangun perekonomian berlandaskan kekuatan sendiri, terutama untuk mencukupi kebutuhan produk pangan (terutama beras) sendiri, hal ini tidak sejalan dengan catatan historis keberadaan dan kelangsungan masyarakat Indonesia. Pengelolaan dan keorganisasian perekonomian padi nasional dewasa ini telah direduksi secara dramatik hingga tingkat kebijakan harga dasar dan penyikapan pasar terhadap relativitas harga serelia di pasar bebas. Hal ini bukan saja akan membahayakan ketahanan sistem sosial ekonomi pedesaan, namun justri akan semakin menguatkan ketergantungan pangan masyarakat Indonesia terhadp resiko ketidakpastian pasar global yang tidak bebas dari intervensi sepihak dari negara-negara besar.

Pemberian otonomi pada pemerintah tingkat II harus dipandang sebagai keputusan dan modal politik yang sangat berharga untuk membangun kembali kepercayaan masyarakat pedesaan terhadap keberadaan pemerintah. Jika keleluasaan otonomi tadi dimanfaatkan secara salah oleh para elit politik dan aparat pemetintah tingkat II, maka peluang mengembalikan kedaulatan masyarakat pedesaan untuk membangun perekonomian nasional akan semakin tertutup. 
ORGANISASI EKONOMI PEDESAAN

Dalam perjalanannya, organisasi KUD mulai menunjukkan ketidak berdayaannya untuk menopang perekonomian pedesaan. BRI unit desa, yang keberadaannya banyak digerakkan oleh kebijakan pemerintah pusat untuk mendukung program pencairan kredit Bimas, juga mengalami nasib seperti KUD. Organisasi ekonomi yang kemudian muncul dan berkembang di pedesaan umumnya adalah penjual saprodi, pedagang pembeli gabah petani dan pengolah hasil pertanian seperti usaha Rice Milling Unit (RMU). Organisasi tadi umumnya dikendalikan secara perorangan., dan hanya sedikit yang dikelola secara kolektif atau mengikuti pola koperasi. Cara kerja mereka umumnya didasrkan pada dua ciri, yang pertama, mengikuti pola hubungan jual beli biasa. Kedua, mengikuti pola hubungan patronase yang didasarkan pada ikatan kepercayaan personal antara "Sang Patron" dan "Klien"-nya. Sang Patron umumnya adalah penguasa tanah atau pemilik kapital di pedesaan, sedangkan klien adalah petani kecil (berlahan sempit) dan petani tak bertanah.

Kejayaan KUD berakhir, karena melemahnya dukungan pemerintah di satu sisi dan tidak mengakarnya lembaga ini pada kepentingan masyarakat di sisi lain. Dengan gambaran ini dapat dikatakan bahwa pada hampir semua masyarakat pedesaan mengalami "kekosongan kelembagaan", khususnya di bidang ekonomi. Kebanyakan perekonomian pedesaan dikendalikan oleh pelakupelaku ekonomi berkapital besar di perkotaan atau agen dari pemilik kapital besar tadi. Oleh sebab itu terutama pada daerah yang kekuatan kelembagaan ekonomi setempatnya relatif lemah , secara keseluruhan posisi tukar relatif lemah. Gejala yang mudah ditangkap dari gambaran ini adalah bahwa peran pemerintah yang selama ini menggunakan "pendekatan politik kekuasaan" dalam menggerakkan perekonomian pedesaan bisa dikatakan mengalami kegagalan. Proses transformasi kelembagaan perekonomian pedesaan bukan hanya mengalami gejala stagnasi, melainkan juga kemunduran yang serius.

Organisasi ekonomi pedesaan harus dipandang sebagai bagian dari sistem masyarakat pedesaan yang perlu mendapat 
perhatian serius, karena hingga kini aspek organisasi ekonomi ini masih menjadi titik lemah dalam memasuki era pasar bebas. Menurut Uphoff (1992), suatu lembaga atau organisasi lokal yang dinilai bisa mendorong kemajuan masyarakat haruslah mampu menjaring partisipasi masyarakat secara masif (Inayatullah, 1979). Ciri organisasi sosial ( dan ekonomi ) yang berciri monolitik (Tjondronegoro,1977) dan feodalistik sangat kurang sesuai untuk mengantarkan perekonomian pedesaan bisa cepat maju bersamaan dengan pencapaian tujuan keadilannya. Selama ini keorganiosasian atau kelembagaan ekonomi pedesaan, seperti KUD (yang dibentuk pemerintah), secara akademik juga perlu dicurigai dalam mendorong terjadinya polarisasi sosial ekonomi yang tajam di pedesaan (Hayami dan Kikuchi, 1987).

Organisasi ekonomi yang dibangun untuk masa depan masyarakat Indonesia yang masih sarat dengan ciri agraris haruslah berorientasi pada penguatan ekonomi pedesaan. Salah satu tujuan utamanya adalah mendorong dihasilkannya produkproduk pertanian dan jasa usaha lainnya yang memiliki daya saing tinggi di pasaran. Oragnisasi semacam ini sudah barang tentu harus bertolak dari kekuatan masyarakat pedesaan itu sendiri.

Dengan organisasi tadi masyarakat pedesaan diharapkan bisa menguasai aset-aset ekonomi strategisnya, baik yang berupa sumberdaya material maupun sumber daya non materialnya. Sebagaimana dikemukakan Sudaryanto dan Pranadji (2000), organisasi ekonomi pedesaan tadi adalah seperti bangunan jaringan kemitraan agribisnis yang seharusnya dikembangkan di pedesaan. Beberapa ciri penting organisasi ekonomi pedesaan yang dinilai mampu untuk meningkatkan daya saing ekonomi pedesaan adalah sebagai berikut :

1. Strategi reformasi organisasi ekonomi di pedesaan sejauh mungkin diarahkan untuk tujuan mengahsilkan produk akhir (misalnya beras kepala), bukan sekedar untuk (misalnya) bahan baku yang harus diolah lagi (misalnya: gabah kering giling) atau sebagai input industri. Organisasi ekonomi desa yang dibangun pemerintah pusat pada masa lalu lebih banyak 
dipusatkan

untuk

mengembangkan

usaha

pertanian sebatas pada kegiatan

usaha tani. Oelh sebab itu pelaku

ekonomi di pedesaan hingga kini belum sepenuhnya bisa menikmati semua hasil nilai tambah produk pertanian padi sawah yang dihasilkan. Sistem agribisnis padi yang ada masih tidak efisien dan tidak mampu bersaing dengan sistem agribisnis padi negara lain, misalnya Vietnam.

2. Konsolidasi fisik cabang-cabang kegiatan agribisnis padi sawah masih sangat lemah. Hal ini bukan saja merupakan titik lemah daya saing agribisnis padi sawah Indonesia, namun juga menjadi sumber pemborosan pemanfaatan sumberdaya pertanian dan memperoleh penanganan secara serius oleh banyak pihak, teruitama kalangan aparat pemerintah.

Upaya mengkonsolidasi seluruh cabang kegiatan dan sumber daya agribisnis padi sawah di pedesaan merupakan hal yang mendesak, karena melalui cara ini terbuka kemungkinan terjadinya penguatan jaringan dan sistem agribisnis padi sawah di pedesaan.

3. Dipandang dari keorganisasian ekonomi, jaringan agribisnis yang dibangun di pedesaan seyogyanya diarahkan untuk memperkuat makna pengintegrasian kegiatan agribisnis, yang selama ini masih sangat tersekat-sekat, menjadi bangunan ekonomi yang relatif utuh Tujuan pengintegrasian ini adalah untuk memperoleh dua manfaat sekaligus, yaitu : mewujudkan asas skala ekonomi yang kompetitif (MES=Minimum Economics of Scale) di satu sisi dan untuk menarik seluruh potensi nilai tambah dari keseluruhan jaringan agribisnis padi pada pelaku ekonomi pedesaan di sisi lain. Dengan demikian dapat dikatakan bahwa makna peningkatan efisiensi pada jaringan agribisnis padi sawah tadi sekaligus dalam rangka peningkatan kesejateraan ekonomi masyarakat pedesaan. 
4. Sistem pengintegrasian tadi harus mencakup pula pengembangan kepemilikan jaringan agribisnis secara kolektif. Dengan model penguasaan saham secara kolektif, mengutamakan masyarakat pelaku agribisnis padi di pedesaan sebagai pemilik saham terbesarnya harus mendapat penonjolan. Dalam konsep ini penguasaan secara individual (monopoli) terhadap jaringan atau salah satu cabang agribisnis padi tidak dimungkinkan lagi, sehingga tidak ada konsentrasi penguasaan (modal) agribisnis pada segelintir pemilik modal.

Dengan cara demikian, sebagian besar jaringan agribisnis padi bisa dikuasai masyarakat pedesaan dan interdependensi antar pelaku agribisnis padi diharapkan bisa menjadi relatif seimbang. Dengan kata lain, kecenderungan terjadinya interdependensi antar pelaku agribisnis di pedesaan yang sangat asimetris, seperti yang umum terjadi selama ini, bisa dihindarkan.

5. Dalam rangka membri insentif bagi pelaku ekonomi padi sawah untuk menginvestasikan uang atau aset berharga yang dimilikinya, pengakuan terhadap pemilikan individu pada agribisnis di pedesaan masih dimungkinkan. Hanya saja pemilikan individu tadi seyogyanya diterjemahkan dalam bentuk pemilikan saham, bukan pada (misalnya) pemilikan secara monopolistik atas suatu cabang kegiatan agribisnis tertentu. Sebagai contoh, dengan memonopoli jaringan pemasaran, maka hampir seluruh nilai tambah agribisnis padi sawah di pedesaan bisa dikuasainya, dan hanya sebagian kecil yang jatuh di tangan petani di pedesaan. Secara keorganisasian bisnis, pemilikan individu harus sebatas kontribusi modal. Sedangkan dari segi pengambilan keputusan (manajemen) kegiatan usaha tetap harus dilakukan mengikuti kaidah-kaidah manajemen futuristik, seperti yang akan 
dijelaskan kemudian.

Beberapa syarat penting yang harus diperhatikan dalam menghela reformasi keorganisasian ekonomi pedesaan berbasis pengembangan jaringan kegiatan agribisnis pada adalah ; Pertama, perlu adanya kekuatan lembaga penunjang yang setiap saat siap melayani keperluan kegiatan agribisnis. Lembaga yang dimaksud mencakup tersedianya sistem keuangan dan perkreditan mikro, pelayanan informasi

pemasaran hasil dan kebutuhan inovasi untuk pengembangan daya saing produk agribisnis padi setempat. Kedua, prasarana ekonomi dan jaringan telekomunikasi yang memadai di pedesaan, sehingga dinamika dan perkembangan kegiatan agribisnis padi di pedesaan bisa seirama dengan tuntutan kebutuhan pasar. Ketiga, adanya peraturan pemerintah, yang merupakan representasi kepentingan masyarakat banyak, yang diarahkan untuk membatasi praktek monopoli pada kegiatan agribisnis yang sedang dibangun sebagai basis kegiatan perekonomian pedesaan. Keempat, adanya sistem penegakan hukum yang jelas dan tegas, sehingga berbagai macam konflik yang terjadi antar pelaku ekonomi di pedesaan bisa diselesaikan dengan adil.

$$
\text { Organisasi }
$$

(dan manajemen) merupakan bagian dari konsep kelembagaan yang mengarah pada pekerjaan yang dilakukan secara kolektif. Ini dilakukan dengan pengertian bahwa jika seseorang bekerja secara individual maka hasilnya akan kalah efisien dan efektif dibanding jika individu-individu tadi menjalin hubungan kerja sama dengan kesepakatan dan cara tertentu. Setiap pelaku ekonomi yang terorganisasikan harus mempunyai peran yang jelas, karena dengan demikian akan bisa dicapai efisiensi dan kefektifan kerja yang relatif tinggi.

\section{SISTEM MANAJEMEN EKONOMI}

Penyelenggaraan keorganisasian ekonomi pedesaan memerlukan dukungan kelembagaan atau sistem manajemen yang memberikan cukup garansi untuk dikembangkannya sistem agribisnis padi yang sehat dan berdaya saing tinggi di pedesaan. Sistem manajemen yang dimaksud fokusnya ditekankan pada bagaimana 
pengambilan keputusan bersama (kolektif) dapat dilakukan secara baik. Perlu ditekankan bahwa sistem manajemen yang dimaksud disini adalah berkaitan dengan pemberdayaan "modal sosial" setempat dalam rangka meningkatkan daya saing ekonomi masyarakat pedesaan, (bukan penerapan sistem manajemen militer untuk mengatasi situasi keadaan gawat atau perang).

Sejalan dengan reformasi untuk memperkuat kelembagaan perekonomian desa, sistem pengambilan keputusan (misalnya) pada kegiatan keorganisasian agribisnis padi sawah di pedesaan seyogyanya memperhatikan kaidah-kaidah tertentu yang bersifat universal. Berdasarkan hal itu keputusan yang dihasilkan bukan saja memepunyai kekuatan untuk meningkatkan daya saing kegiatan agribisnis padi yang ada, namun yang juga lebih penting adalah meningkatkan keseluruhan daya saing ekonomi pedesaan. Sistem manajemen untuk penguatan kelembagaan ekonomi desa tadi kita sebut saja manajemen futuristik, yang secara sederhana dapat dilihat pada tabel berikut :
Manajemen Konvensional

Manajemen Futuristik

1. Akuntabilitas tidak jelas

2. Transparansi tidak jelas

1. Akuntabilitas harus

3. Tidak demokratik

4. Rasionalitas tidak jelas jelas

5. Tidak mudah diaudit terbuka

2. Transparansi harus jelas

3. Harus demokratik

4. Rasionalitas harus jelas

5. Mudah diaudit terbuka

Perkembangan sistem manajemen dalam keorganisasian ekonomi pedesaan selama ini menunjukkan arah yang kurang jelas, ke arah maju atau mundur. Tabel diatas menunjukkan perbedaan antara sistem manajemen konvensional dan sistem manajemen Futuristik dalam pengelolaan keorganisasian perekonomian pedesaan. Tampak jelas bahwa untuk penguatan keorganisasian perekonomian pedesaan dibutuhkan sistem manajemen baru dan maju, yang dengan itu keorganisasian tadi akan memiliki daya antisipasi dan daya saing yang relatif tinggi. Pada butir satu hingga butir empat mencerminkan bagaimana pengambilan keputusan pada kegiatan ekonomi dalam suatu organisasi ekonomi pedesaan suadah 
harus mengadopsi ciri-ciri futuristik (Anonimous, 2001).

Dalam

rangka

memposisikan masyarakat pedesaan untuk melaju pada rel kemajuan ekonomi, masyarakat pedesaan tadi harus dipandang sebagai entitas ekonomi yang mandiri. Selama ini istilah masyarakat pedesaan sering dipinjam sebagai komoditas pembangunan dan dijadikan "obyek bisnis" (politik) di kalangan elit atau birokrat pemerintah baik di tingkat pusat maupun daerah. Sebagai obyek bisnis politik, sistem akuntabilitas yang ditunjukkan untuk kemajuan ekonomi pedesaan menjadi kabur. Dalam hal ini, masyarakat pedesaan seakan-akan tidak boleh mempunyai hak meminta pertanggung jawaban para elit politik, birokrat, pemerntah dan LSM terhadap apa yang dilakukan dengan mengatasnamakan dirinya. Untuk lebih menjamin kemajuan perekonomian masyarakat pedesaan, sistem akuntabilitas terhadap setiap pengambilan keputusan yang menyangkut kepentingan masyarakat banyak di pedesaan haruslah jelas.

Berkaitan

dengan

ketidakjelasan akuntabilitas tadi, biasanya akan diikuti juga dengan kurang adanya transparansi dalam setiap pengambilan keputusan yang dilakukan para elit politik, pemerintah maupun LSM terhadap kepentingan masyarakat pedesaan. Prinsip kejelasan transparansi ini juga sejalan dengan upaya membangun

sistem masyarakat madani (civil society) yang lebih demokratis, tata penyelenggaraan pemerintahan yang baik ( good governance and clean governance ). Jika hal ini berhasil ditegakkan pada seluruh jaringan masyarakat komunal di pedesaan, maka dalam waktu tertentu indikasinya harus dapat ditampakkan oleh adanya peningkatan daya saing perekonomian pedesaan secara signifikan.

Jika prinsip akuntabilitas dan transparansi dalam pengambilan keputusan diniatkan untuk ditegakkan secara konsekuen, maka demokratisasi dalam setiap pengambilan keputusan pun akan relatif mudah dukembangkan. Salah satu syarat dari akuntabilitas dan trasparansi yang dimaksud adalah menghargai kepentingan masyarakat banyak di pedesaan. Melalui cara demikian upaya menempatkan kepentingan masyarakat sebagai bagian 
utama atau subyek pembangunan perekonomian pedesaan akan menjadi lebih mudah diwujudkan. Dengan kata lain, demokratisasi terhadap setiap pengambilan keputusan di pedesaan harus menjadi bagian penting dari penerapan sistem manajemen futuristik, terutama dalam rangka peningkatan daya saing perekonomian pedesaan di arena pasar bebas.

Istilah membangun dan melakukan pengawasan pembangunan dari bawah slogan sudah lama didengungkan. Namun hal itu masih terbatas sebagai slogan politik. Sistem pengawasan dari bawah yang rasional dan berdasarkan alasan yang masuk akal pada keorganisasian perekonomian pedesaan pada masa lalu dalam kenyataan masih menjadi barang langka. Sebagai gambaran, hampir semua manajemen KUD dan pemerintahan desa selama lebih dari 30 tahun tidak mendasarkan pada prinsip ini. Oleh karena itu bisa dimengerti jika manfaat dari

penyelenggaraan KUD dan pemerintahan desa dalam kenyataan sedikit sekali yang bisa dirasakan golongan masyarakat di pedesaan.
Melalui penegakan asas rasionalitas dalam proses pengauditan terhadap setiap pengambilan keputusan, maka pengelolaan

keorganisasian perekonomian pedesaan diperkirakan akan lebih mudah disesuaikan dengan dinamika dan tantangan kemajuan.

\section{TATA NILAI DAN KUALITAS SUMBER DAYA MANUSIA}

Tata nilai kemajuan, bukti empiris menunjukkan bahwa perkembangan dan kemajuan ekonomi suatu negara atau masyarakat tidak hanya ditentukan oleh kekayaan atau besarnya sumber daya alam yang dipunyai, melainkan juga tergantung pada pengusaan aspek kelembagaannya. Bahkan di banyak kasus, aspek kelembagaan, atau menurut Sorokin (1964) sumber daya non material inilah yang lebih menentukan kamjuan ekonomi suatu masyarakat. Sebagai contoh, Jepang dan Singapura adalah dua negara yang mempunyai kekayaan sumber daya alam relatif sedikit, namun dari segi kecepatan perkembangan ekonomi masyarakatnya sulit ditandingi oleh hampir semua masyarakat negara di 
dunia ini. Salah satu aspek kelembagaan yang dimaksud adalah dianut atau tidaknya tata nilai yang mengindikasikan kemajuan yang meluas di masyarakat.

Pengertian reformasi kelembagaan ekonomi pedesaan harus mempunyai makna peningkatan daya saing ekonomi masyarakatnya. Makna kelembagaan memuat aspek "isi" seperti yang dikemukakan oleh Lauer (1982) tidak hanya pada "bentuk luar"

atau fisiknya. Salah satu isi penting dari kelembagaan adalah tata nilai yang menghidupkan fungsi kelembagaan ekonomi. Jika kelembagaan ekonomi desa terisi oleh tata nilai terbelakang, maka hampir dapat dipastikan daya saing agribisnis padi dan ekonomi masyarkat desa akan relatif rendah.

Reformasi kelembagaan dalam bentuk penonjolan tata nilai kemajuan bukan saja akan mendorong kelembagaan agribisnis dan ekonomi padi di pedesaan lebih cepat maju, namun juga akan meningkatkan daya saing masyarakat itu sendiri di bidang ekonomi. Tata nilai yang populer memajukan masyarakat Jepang adalah dipakainya prinsip rasa malu pada hampir semua elemen kehidupan masyarakatnya. Weber (1964) menyatakan bahwa salah satu satu komponen dari tata nilai kemajuan adalah apa yang disebut "calling" atau penggilan (hati). Pada masyarakat Barat tata nilai tadi dikenal dengan "Protestant Ethics", dan itu yang diklaim sebagai faktor penjelas mengapa masyarakat di dunia Barat lebih maju dibanding dengan masyarakat lainnya. Dalam istilah lain Hagen (1962) menyatakan bahwa faktor personalitas menjadi penentu kemajuan ekonomi sutau masyarakat. Lebih -lebih lagi jika penerapan aspek personalitas tadi tidak memperoleh tantangan serius dari kebanyakan anggota masyarakat.

Kualitas

$S D M$, Keterbelakangan atau adanya krisis ekonomi pada suatu masyarakat umumnya disebabkan oleh rendahnya kualitas SDM yang ada pada masyarakat yang bersangkutan. Jika kompetensi atau kualitas SDM dalam masyarakat pedesaan rendah, maka hampir pasti tingkat kemajuan perekonomian masyarakat akan rendah pula. Lebih dari itu aspek kemajuan kehidupan lainnya juga akan rendah. 
Secara keseluruhan daya saing atau daya penyesuaian diri masyarakat tersebut terhadap perubahan relatif kurang mantap dan seringkali kalah cepat dibanding dengan kecepatan perubahan itu sendiri. Aspek kualitas SDM yang dimaksud terdiri atas beberapa faktor yang harus dicermati, yaitu :

1. Keterampilan individu atau individu skill yang bisa diandalkan untuk menopang produktivitas kerja atau daya saing dirinya di bidang pekerjaan yang ditekuninya

2. Kematangan emosional yang tinggi akan sangat membantu seseorang mengoptimalkan kemampuannya.

3. Kemampuan bekerja secara tim yang relatif baik akan memberikan rangsanganpada orang lain untuk lebih sering mengajak dirinya bekerja sama secara terorganisasi

4. Kemampuan anggota masyarakat menghargai tata nilai maju bisa dianggap sebagai salah satu ciri penting tingginya kualitas SDM

5. Memiliki sifat dan pengetahuan tentang pentingnya menjunjung tinggi penerapan manajemen futuristik

\section{KESIMPULAN DAN IMPLIKASI}

\section{KEBIJAKAN}

1. Reformasi Kelembagaan untuk penguatan perekonomian padi dan pedesaan haru sdilihat dalam bingkai keputusan politik, dan selanjutnya keputusan politik tersebut harus diterjemahkan secara opersional dalam bentuk perumusan

kebijakan

pembangunan pedesaan yang sarat dengan azas representasi kepentingan

masyarakat pedesaan.

2. Reformasi kelembagaan pedesaan harus dipandang sebagai bagian pengembalian dan pengembangan kepercayaan masyarakat pedesaan yang selama ini terampas akibat kesalahan dalam pendekatan pembangunan yang dijalankan oleh elit politik, birokrat dan pemerintah.

3. Secara umum dapat dikatakan bahwa penguatan lembaga

pedesaan sebagai penggerak ekonomi pedesaan adalah suatu upaya yang tidak mudah dan tidak bisa dilakukan dengan 
tergesa-gesa apalagi tanpa konsep yang bisa diandalkan

4. Reformasi kelembagaan keorganisasian ekonomi petani di pedesaan seharusnya bisa dipandang sebagai kegiatan yang terus-menerus tanpa batas waktu hingga terwujud ekonomi kerakyatan berbasis sumber daya pertanian yang kuat.

5. Dalam mewujudkan kelembagaan ekonomi pedesaan yang kuat kelompok tani bisa jadi titik untuk membangkitkan penguatan ekonomi pedesaan yang dimaksud .

6. Untuk mewujudkan organisasi agribisnis padi sawa dan perekonomian desa yang tangguh perlu dikembangkan sistem tata nilai dan kepemimpinan yang mengarah pada kemajuan ekonomi

7. Upaya reformasi kelembagaan ekonomi pedesaan pada masa datang harus sejalan dengan upaya mentranformasikan tatanan pemerinrahan dan pengelolaan sumber daya ekonomi yang lebih otonom hingga tingkat desa.
DAFTAR PUSTAKA

Anonimous. 2001. Pengembangan

Kelompok Tani Sebagai Unit Ekonomi :

Ringkasan

Pengkajian. Pusat

Pengkajian SDM Pertanian, Badan

Pengembangan

SDM dan Penyuluhan

Pertanian. Jakarta.

Hagen, E. 1962. On The Theory of

Social Change : "How Economics

Growth Begins?".

The Doorsey, Inc. Illinois. Hayami, Y dan M.Kikuchi. 1987. Dilema Ekonomi Desa : Suatu Pendekatan Ekonomi

terhadap Perubahan Kelembagaan di Asia. Yayasan Obor Indonesia.

Jakarta.

Inayatullah. 1979. Conceptual

Framework for Country Studies of Rural Development.

In Approach to Rural

Development : Some Asian Experiences (edited by

Inayatullah. Asian and Pacifis Development Administration Center.

Kualalumpur. 
Kuhn. T.S. 1967. The Structural of

Scientific Revolutions. Phoenix Books,

The University

of Chicago Press. Chicago.

Lauer, R.H. 1982. Perspective on Social

Change. Allyn and Bacon, Inc. Boston

Pranadji, T. 1999. Desentralisasi dan

Percepatan Transformasi Agribisnis

Secara

Berkelanjutan dalam

Dinamika Inovasi Sosial Ekonomi dan

Kelembagaan

Pertanian ( Editor I.W.

Rusastra ). Pusat Penelitian Sosial

Ekonomi

Pertanian. Bogor.

Pranadji, T. 2002. Reformasi

Kelembagaan Ekonomi Pedesaan yang

Tertunda di Era

Otonomi Daerah. Seminar

Nasional dan Rekonsiliasi Mahasiswa

Pertanian

se-Indonesia bertema

"Studi Kritis Pembangunan Pertanian

dalam Dua

Tahun Otonomo Daerah

Menuju Kesejahteraan Masyarakat

Petani" di

Fakultas Pertanian,

Universitas Gadjah Mada, 22 Mei 2002. Jogjakarta.
Scott, J.C. 1989. Moral Ekonomi Petani :

Pengolahan dan Subsistensi di Asia

Tenggara. LP3ES. Jakarta

Sorokin, P. 1964. Contemporary

Sociology Theories : The First Quarter

of Twentieth

Century. Harper and Row

Publishers. New York

Sudaryanto, T. dan T. Pranadji.2000.

Peran Kewirausahaan dan

Kelembagaan

( Kemitraan) dalam

Peningkatan Daya Saing Produk

Tanaman Pangan

dalam Prosiding Simposium

"Tonggak Kemajuan Teknologi Produksi

Tanaman Pangan". Pusat

Penelitian dan Pengembangan Tnaman

Pangan.

Bogor.

Tjondronegoro,S.M.P. 1977. The

Organization Phenomenon and Planned

Development

in Rural Communities of

Java: A Case Stusy of Kecamatan

Cibadak, West

Java and Kecamatan

Kendal, Central Java. University of Indonesia 
Uphoff,N. 1992.Local Institutionand

Participation for Sustainable

Development (Gate-

keeper Series No.31)

Weber, M. 1964. TheHeory of Social an

Ecionomic Oraganization, (trasnlate by
AM

Henderson and T. Sparson).

The Press. New York. 